\title{
Experimental Studies on Controlled Low Strength Material Using Stone Dust and EPS Beads
}

\author{
V. R. Marjive, V. N. Badwaik, and B. Ram Rathan Lal
}

\begin{abstract}
In India, aggregate crusher unit produces enormous quantities of stone dust, a by-product produced during crushing of stone. Stacking or disposal of such large quantities of stone dust in environmental friendly manner is a serious concern for developing countries like India. Efforts are underway to utilise stone dust in civil engineering construction industries so that minimizing the threat caused to environment in the direction of sustainable development. This paper pertain the results of the compressive strength experimental study carried out on controlled low strength material (CLSM) prepared using stone dust and expanded polystyrene beads (EPS). The experiments were conducted by adding EPS beads with different mix proportions with respect to the weight of stone dust. The mix ratio percentages used in the present study are $0.033,0.099$, and 0.165 . The density of EPS beads used is 22 $\mathrm{kg} / \mathrm{m}^{3}$. Cubical specimen of size $70 \mathrm{~mm} \times 70 \mathrm{~mm} \times 70 \mathrm{~mm}$ was used for evaluating the compressive strength of CLSM for curing periods of 7 and 14 days. The results indicate that the compressive strength of CLSM significantly influenced by the curing period and mix ratios. For a particular mix ratio value, compressive strength of CLSM increased with increasing curing period and for particular curing period days it decreased with increasing mix ratios. The weight of CLSM is decreased with increasing mix ratios. The results indicate that CLSM with acceptable strength is attainable using stone dust and EPS beads.
\end{abstract}

Index Terms - Compressive strength, controlled low strength material (CLSM), expanded polystyrene (EPS) beads, stone dust and sustainable development.

\section{INTRODUCTION}

In recent years the use of conventional materials like sand in civil engineering construction industry is increasing day by day. Due to huge rise in construction activities, there has been lot of scarcity of these materials leads to environmental imbalance, and also increase the final cost of construction. Due to ever increasing demand for conventional materials made researchers to search for alternative materials to use successfully in the civil engineering projects. One of the materials is stone dust; a product produced from the stone crushing industries has shown good results when it has been used as alternative to conventional materials. According to Soosan et al. [1], 200 million tons of stone dust is being generated every year in India.

This material can be used in road works and geotechnical applications effectively as it gradation does not suit the requirement of concrete works.

Dutta and Sarda [2] presented the comparative study of

Manuscript received December 22, 2014; revised February 27, 2015.

V. R. Marjive, V. N. Badwaik, and B. Ram Rathan Lal are with Department of Civil Engineering, K.I.T.S. Ramtek - 441106, India (e-mail: vaishali.marjive@ rediffmail.com, rathan_lal@yahoo.com). compaction and CBR behaviour of stone dust reinforced with low density polyethylene (LDPE) and high density polyethylene (HDPE) waste plastic strips. Kandolkar and Mandal [3] studied stone dust for tapping its potential as an alternative backfill material for retaining walls. Edeh et al. [4] discussed the results of a laboratory evaluation of the characteristics of Reclaimed Asphalt Pavement (RAP) and Quarry Waste (QW) blends with a view to determine their suitability for use as flexible pavement material. The test results show that the properties of RAP waste improved with QW treatment. Lohani et al. [5] studied optimum utilization of quarry dust as partial replacement of sand in concrete. In developing countries like India, quarry dust has been rampantly used in different construction purposes but replacement technology has emerged as an innovative development to civil engineering material.

Expanded polystyrene (EPS) beads are produced a step before the production of block i.e., the blocks are made by fusion of beads. EPS beads are colourless and consists polystyrene and dissolved pentane [6]. EPS is non-biodegradable, chemically inert in both soil and water. EPS is hydrophobic in nature. It has closed cell structure which prevents absorption of water in it. It is highly compressible material available in different types for specific purpose. Various studies have been carried out on utilization of EPS beads as a fill material by blending them with soil and cement as a binder material.

Liu et al. [7] reported that the density of lightweight fill can be effectively controlled by using amount of expanded polystyrene beads in making the lightweight fill and can be used as lightweight fill material in construction of embankments, abutments and backfilling of retaining walls. Wang and Miao [8] prepared a geomaterial composed of EPS beads mixed with river sand and cement for using in the construction of highway embankment. Padade and Mandal [9] proposed a geomaterial by blending fly ash with EPS beads and using cement as binder. They reported that the compressive strength of geomaterial is increases with increasing cement content and curing period.

Controlled Low Strength Material (CLSM), as defined by the American Concrete Institute Committee 229 [10], is a self-flowing cementitious material consisting typically of Portland cement, fine aggregates, supplementary cementing materials and water. CLSM is capable of developing required low levels of strength in the range of 1 to10 MPa. Horiguchi et al. [11] discussed the applicability of new controlled low-strength materials (CLSM) which include incinerated sewage sludge ash. The incinerated sewage sludge ash was used as a replacement for fly ash, which is the main component of CLSM. The test results also confirm that a wide range of municipal solid wastes could be used as 
materials in the new green CLSM. Gemperline and Durham [12] investigated the engineering characteristics of recycled materials in a controlled low strength material. Strength requirement are low in comparison to typical structural concrete.

The present study mainly focus on experimental studies carried out on newly developed CLSM using stone dust and EPS beads with cement as binding agent. Compression tests were carried out on prepared cubical specimen for curing period of 7, 14 days and the results are incorporated in the paper.

\section{CHARACTERIZATION OF MATERIAL}

\section{A. Expanded Polystyrene (EPS) Beads}

The EPS beads were procured from Biogen India Pvt. Ltd., Nagpur, India and were used in present study. The density of EPS beads is $22 \mathrm{~kg} / \mathrm{m}^{3}$ and they are spherical in shape. The diameter of EPS beads are 2 to $3 \mathrm{~mm}$. Fig. 1 shows EPS beads used in the experimental investigation.

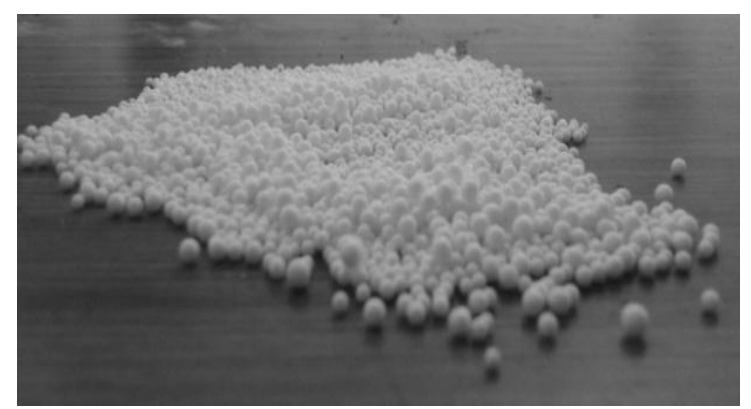

Fig. 1. Photograph of EPS beads.

\section{B. Stone Dust}

Stone dust was collected from Hot Mix Plant near Aamdi, Ramtek (Tah.), Nagpur (Dist.), Maharashtra, India. Fig. 2 shows the photograph of stone dust used in the experimental study. The physical properties of the stone dust are given in Table I.

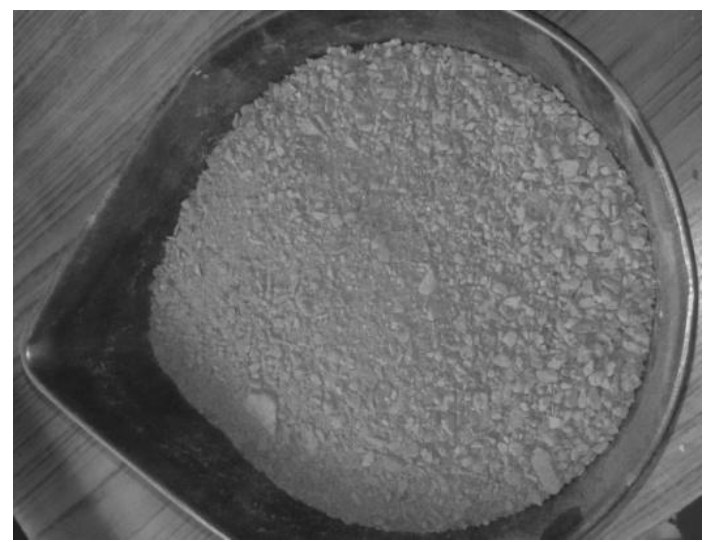

Fig. 2. Photograph of stone dust.

TABLE I: PHYSICAL PROPERTIES OF STONE DUST

\begin{tabular}{ll}
\hline \hline Properties & Value \\
\hline Specific gravity $(\mathrm{G})$ & 2.6 \\
Uniformity coefficient $\left(\mathrm{C}_{\mathrm{u}}\right)$ & 11.35 \\
Coefficient of curvature $\left(\mathrm{C}_{\mathrm{c}}\right)$ & 1.85 \\
Dry Unit Weight $\left(\mathrm{kN} / \mathrm{m}^{3}\right)$ & 19.5 \\
Optimum moisture content $(\mathrm{OMC})(\%)$ & 16 \\
\hline \hline
\end{tabular}

\section{EXPERIMENTAL PROGRAM}

In the experimental study effect of different mix ratios on the behaviour of CLSM is investigated by conducting a series of compression tests on the EPS beads reinforced stone dust cubical specimen apart from unreinforced (i.e.,) without EPS beads for a particular percentage of cement mix ratio.

\section{A. Mix Ratios and Preparation of Specimen}

The dry weight of the stone dust $W_{s}$ required to make specimen is calculated using formula $W_{s}=\gamma_{d \max } \times V_{s}$, where $\gamma_{\text {dmax }}$ is maximum dry unit weight of stone dust and $V_{s}$ is volume of stone dust. Volume of dry stone dust $\mathrm{V}_{\mathrm{s}}$ is calculated by using the formula $V_{s}=V-V_{b}$, where $\mathrm{V}$ is total volume of specimen $\left(343 \mathrm{cc}\right.$ ) and $V_{\mathrm{b}}$ is volume of EPS beads. For initial mix ratio $\mathrm{V}_{\mathrm{b}}$ was considered as $10 \mathrm{cc}$. Weight of beads was calculated by using formula $W_{b}=\rho_{b} \times V_{b}$, where $\rho_{\mathrm{b}}$ is density of EPS beads. Weight of cement to stone dust ratio is taken as constant $10 \%$. Volume of water $V_{w}$ to be added is calculated with respect to weight of stone dust $\left(V_{w}=W_{s} \times\right.$ OMC). In the present study mix ratio is ratio between weight of EPS beads and stone dust. Table II gives the mix ratios and the quantity of materials used to prepare specimens.

The dry stone dust was weighed and placed in a mixing container. Then cement was added and dry mixing was performed. The materials were mixed into homogeneous mixture by hand. For the compound mixer water was added slowly and stone dust-cement-water mixture was mixed into homogeneous slurry. The EPS beads were then slowly added to the slurry and mixing was continued until the beads were evenly distributed. After mixing, the slurry was cast into the moulds and kept for setting after setting period all the specimens were removed from the mould and kept for curing in a water tank. Fig. 3 shows mixing of materials to prepare the CLSM specimen. The curing periods used in the experimental program were 7 and 14 days. Fig. 4 shows photograph of curing tank with specimens.

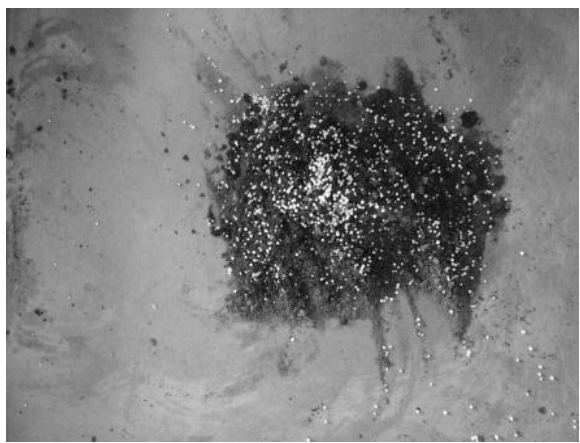

Fig. 3. Mixing of different materials.

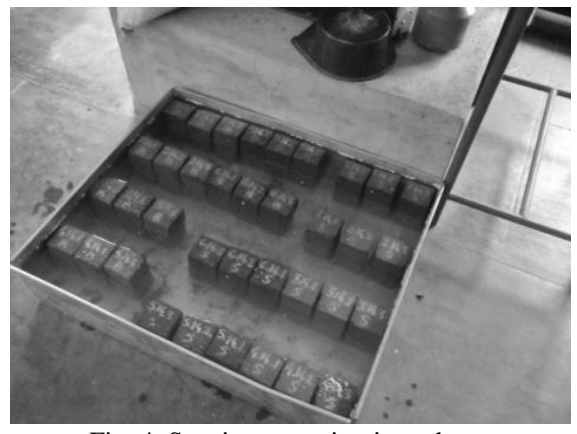

Fig. 4. Specimens curing in tank. 
TABLE II: MIX RATIOS AND QUANTITY OF MATERIALS

\begin{tabular}{|c|c|c|c|c|c|}
\hline Sr. No. & Mix Ratio (\%) & Weight of EPS beads ( $\mathrm{g}$ ) & Weight of stone dust (g) & Weight of cement $(\mathrm{g})$ & $\begin{array}{l}\text { Volume of } \\
\text { water }(\mathrm{ml})\end{array}$ \\
\hline 1 & UR & - & 650 & 65 & 104 \\
\hline 2 & 0.033 & 0.2142 & 649.85 & 64.9 & 103.97 \\
\hline 3 & 0.099 & 0.608 & 614.89 & 61.48 & 98.38 \\
\hline 4 & 0.165 & 0.966 & 583.20 & 58.3 & 93 \\
\hline
\end{tabular}

\section{B. Test Procedure}

After curing the specimen were air dried and weight of each specimen was measured using an electronic weighing balance. The compression test on specimens was performed to measure compressive strength. Compression strength tests were conducted on compression testing machine accommodating the specimen size of $70 \mathrm{~mm} \times 70 \mathrm{~mm} \times 70$ $\mathrm{mm}$ at a constant strain rate of $0.12 \mathrm{~mm} / \mathrm{min}$. A load cell and linear variable differential transducer (LVDT) were used to measure the compressive load and vertical displacement respectively. Load cell and LVDT were connected to a data logger and both are calibrated before use.

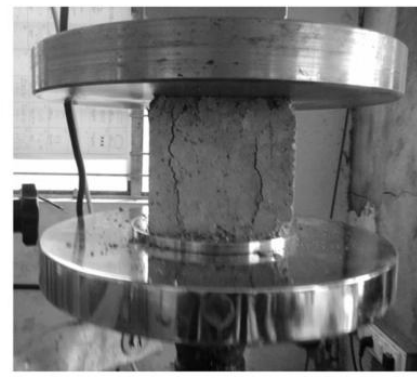

(a)

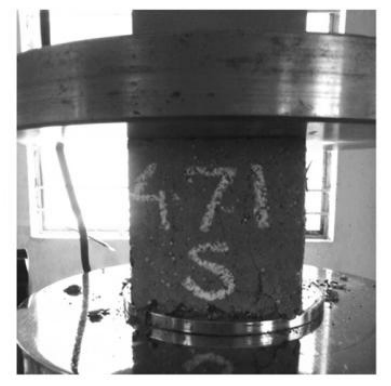

(b)

Fig. 5. Failure patterns (a) unreinforced and (b) reinforced with EPS beads

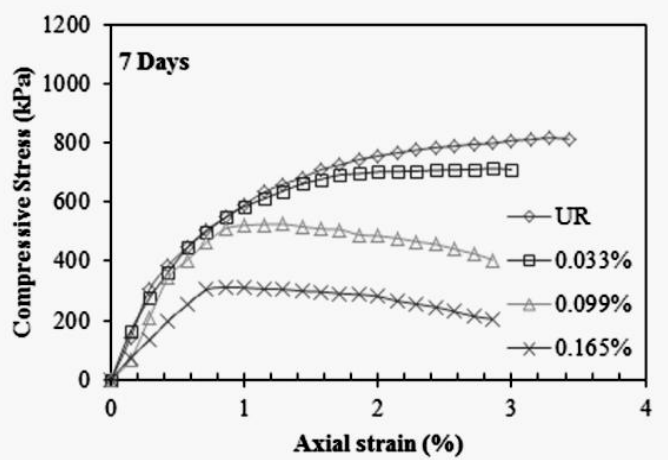

(a)

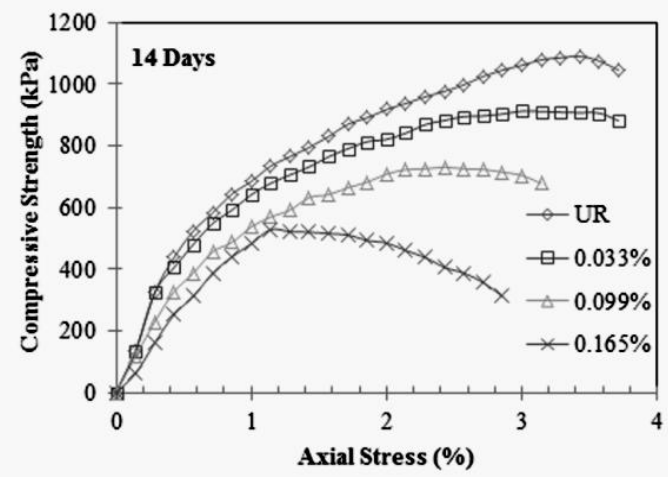

(b)

Fig. 6. compressive stress and axial strain curves for curing period (a) 7 days and (b) 14 days.

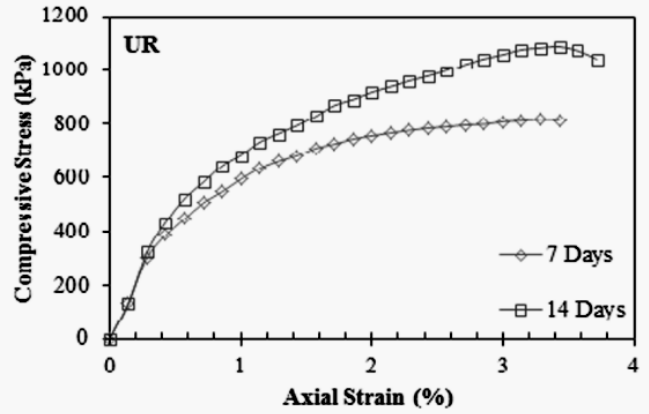

(a)

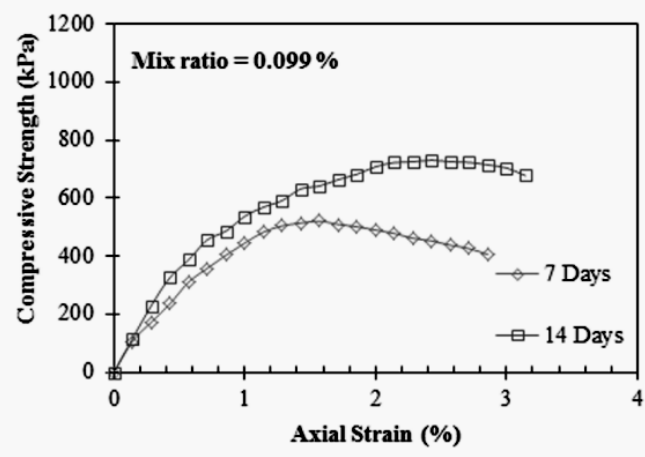

(c)

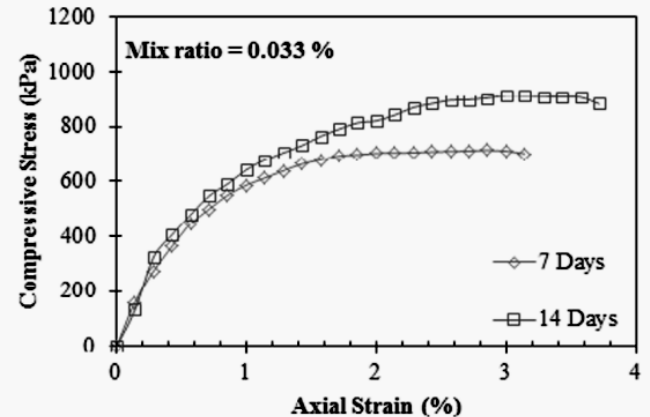

(b)

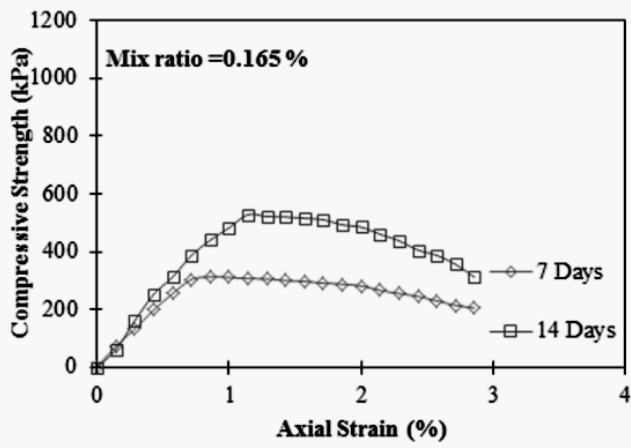

(d)

Fig. 7. Compressive stress and axial strain curves for different mix ratios (a) Unreinforced, (b) $0.033 \%$, (c) $0.099 \%$, (d) $0.165 \%$ 


\section{RESUlTS AND DisCUSSION}

Under the axial compressive load the failure pattern of specimen was observed. All the specimens were failed by showing distinct failure planes either in vertical or in diagonal pattern. Fig. 5 (a) and Fig. 5 (b) show the failure pattern of unreinforced and EPS beads reinforced stone dust specimen. All the specimens were failed in axial strain range of 0.8 to $3.5 \%$.

The density of the CLSM was significantly influenced by the mix ratios. The density of unreinforced specimen was $2270 \mathrm{~kg} / \mathrm{m}^{3}$. By adding $0.033 \%-0.165 \%$ of EPS beads to the specimen the density of CLSM specimens were decreased and the values are in the range of $2186-1880 \mathrm{~kg} / \mathrm{m}^{3}$. With addition of EPS beads in the range $0.033 \%-0.165 \%$, the density of CLSM specimen was decreased from $4 \%$ to $17 \%$.

\section{A. Stress - Strain Pattern}

Fig. 6 shows the relationship between compressive stress and axial strain with different mix ratios for both 7 and 14 days of curing period. For all the mix ratios including unreinforced specimen non-linear relationship was observed between compressive stress and axial strain. For each curing period, with increase in the mix ratio values the stiffness of the specimen is decreased.

Relationship between compressive stress and axial strain for different curing periods for all the mix ratios is shown in Fig. 7. In all the cases the relation between compressive stress and strain was observed to be non-linear. The stiffness of the material was increased with increasing the number of curing days. For all the mix ratios, 14 days cured specimen is having more stiffness than 7 days cured specimen.

Compressive strength of the prepared specimen was significantly influenced by the curing period and mix ratio values. Table III gives the compressive strength for all mix ratios for both 7 and 14 days of curing period. For each mix ratio 14 days strength was higher compared with 7 days strength. Compressive strength value was decreased with increasing the percentage of EPS beads in the specimen.

TABLE III: COMPRESSIVE STRENGTH OF SPECIMEN

\begin{tabular}{lcc}
\hline \hline Mix ratio (\%) & \multicolumn{2}{c}{ Compressive strength $(\mathrm{kPa})$} \\
\cline { 2 - 3 } & 7 Days & 14 Days \\
\hline UR & 819.2 & 1090.8 \\
0.033 & 715.5 & 912.8 \\
0.099 & 521 & 731 \\
0.165 & 312.2 & 528.6 \\
\hline \hline
\end{tabular}

\section{CONCLUSION}

An experimental study was carried out for finding out the compressive strength of CLSM prepared by using EPS beads and stone dust. From the study following conclusions are drawn.

Compressive strength values of CLSM were significantly influenced by the mix ratios and curing period. These values were decreased with increasing mix ratio values and for a particular mix ratio, compressive strength was increased with increasing curing period. Curing period of 14 days CLSM specimen have higher compressive strength with respect to curing period of 7 days. The density of CLSM was decreased with increasing EPS beads percentages. The density of CLSM specimen was decreased from $4 \%$ to $17 \%$ with addition of EPS beads in the range $0.033 \%-0.165 \%$. Stress-strain behaviour was also significantly affected by all the mix ratios used for preparation of CLSM. Non-linear stress strain relation was observed and all the specimens were failed in axial strain range of $0.8 \%$ to $3.5 \%$.

\section{REFERENCES}

[1] T. G. Soosan, A. Shridharan, B. T. Jose, and B. M. Abraham, "Utilization of quarry dust to improve the geotechnical properties of soilsin highway construction," Geotechnical Testing Journal, ASTM, vol. 28, no. 4, pp. 1-10, 2005.

[2] R. K. Dutta and V. K. Sarda, "A Comparative study of compaction and CBR behaviour of stone dust reinforced with waste plastic strips," International Journal of Geotechnical Engineering, vol. 2, pp. 255-264, 2008.

[3] S. S. Kandolkar and J. N. Mandal, "Direct shear tests on stone dust," in Proc. the Indian Geotechnical Conference, 22-24 th December-2013, 2013, pp. 1-6.

[4] J. E. Edeh, M. Joel, and A. Okpe, "Laboratory evaluation of reclaimed asphalt pavement-quarry waste blends as unbound highway pavement material," Advances in Civil Engineering Materials, ASTM, vol. 2, no. 1, pp. 110-120, 2013.

[5] T. K. Lohani, M. Padhi, K. P. Dash, and S. Jena, "Optimum utilization of quarry dust as partial replacement of sand in concrete," International Journal of Applied Sciences and Engineering Research, vol. 1, no. 2, pp. 391-404, 2012

[6] J. S. Horvath, "Expanded polystyrene geofoam: an introduction to material behaviour," Geotextiles and Geomembranes, vol. 13, pp. 263-280, 1994.

[7] H. L. Liu, A. Deng, and J. Chu, "Effect of different mixing ratios of polystyrene pre-puff beads and cement on the mechanical behaviour of lightweight fills," Geotextiles and Geomembranes, vol. 24, pp. 331-338, 2006.

[8] F. Wang and L. Miao, "A Proposed lightweight fill for embankment using cement treated yangzi river sand expanded polystyrene beads," Bulletin of Engineering Geology and Environment, vol. 68, pp. 517-524, 2009.

[9] A. H. Padade and J. N. Mandal, "Expanded polystyrene-based geomaterial with fly ash," International Journal of Geomechanics, ASCE, 2014.

[10] American Concrete Institute Committee 229, "Controlled low-strength materials (CLSM), ACI 229R-94," Concrete International, vol. 16, no. 7, pp. 55-64, 1994

[11] T. Horiguchi, R. Fujita and K. Shimura, "Applicability of controlled low-strength materials with incinerated sewage sludge ash and crushed-stone powder," Materials in Civil Engineering, ASCE, vol. 23, no. 6 , pp. 767-771, 2011.

[12] C. S. Gemperline and S. Durham, "Beneficial use of recycled materials in controlled low strength materials," in Proc. International Conference on Pipelines and Trenchless Technology, ASCE, 2013, pp. 1305-1316.

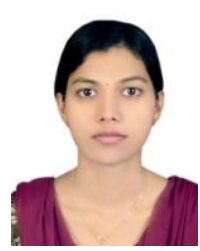

Vaishali R. Marjive was born in Ramtek, Nagpur (Dist.), Maharashtra, India, in 1990. She received her B.E. in civil engineering from Nagpur University, Maharashtra, India in 2012.

She is presently pursuing M.Tech from Nagpur University. She had one year of teaching experience in the field of civil engineering.

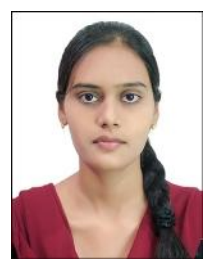

Vaishali N. Badwaik was born in Bhandara (Dist.), Maharashtra, India, in 1990. She received her B.E. in civil engineering from Nagpur University, Maharashtra, India in 2013.

She is presently pursuing M.Tech from Nagpur University, India. 